\title{
Isolation and linkage mapping of NBS-LRR resistance gene analogs in red raspberry (Rubus idaeus L.) and classification among 270 Rosaceae NBS-LRR genes
}

\author{
Suren K. Samuelian • Angela M. Baldo • \\ Jeremy A. Pattison • Courtney A. Weber
}

Received: 7 January 2008 /Revised: 4 March 2008 / Accepted: 4 April 2008 / Published online: 10 June 2008

(C) Springer-Verlag 2008

\begin{abstract}
Plant $R$ genes confer resistance to pathogens in a gene-for-gene mode. Seventy-five putative resistance gene analogs (RGAs) containing conserved domains were cloned from Rubus idaeus L. cv. 'Latham' using degenerate primers based on RGAs identified in Rosaceae species. The sequences were compared to 195 RGA sequences identified from five Rosaceae family genera. Multiple sequence alignments showed high similarity at multiple nucleotidebinding site (NBS) motifs with homology to Drosophila Toll and mammalian interleukin-1 receptor (TIR) and non-TIR RNBSA-A motifs. The TIR sequences clustered separately from the non-TIR sequences with a bootstrap value of $76 \%$.
\end{abstract}

Communicated by: J. Davis

Electronic supplementary material The online version of this article (doi:10.1007/s11295-008-0160-2) contains supplementary material, which is available to authorized users.

S. K. Samuelian · A. M. Baldo · J. A. Pattison · C. A. Weber $(\triangle)$ New York State Agricultural Experiment Station,

Cornell University, 630 West North St.,

Geneva, NY 14456, USA

e-mail: caw34@nysaes.cornell.edu

\section{S. K. Samuelian}

Center for Viticulture and Small Fruit Research,

Florida A\&M University,

6505 Mahan Drive, Tallahassee

FL 32317, USA

A. M. Baldo

USDA-ARS Plant Genetic Resources Unit,

630 W. North St., Geneva, NY 14456, USA

Present address:

J. A. Pattison

Virginia Polytechnic Institute and State University,

Southern Piedmont AREC, 2375 Darvills Road,

Blackstone, VA 23824, USA
There were 11 clusters each of TIR and non-TIR type sequences of multiple genera with bootstrap values of more than $50 \%$, including nine with values of more than $75 \%$ and seven of more than $90 \%$. Polymorphic sequence characterized amplified region and cleaved amplified polymorphic sequence markers were developed for nine Rubus RGA sequences with eight placed on a red raspberry genetic linkage map. Phylogenetic analysis indicated four of the mapped sequences share sequence similarity to groupTIR I, while three others were spread in non-TIR groups. Of the 75 Rubus RGA sequences analyzed, members were placed in five TIR groups and six non-TIR groups. These group classifications closely matched those in 12 of 13 studies from which these sequences were derived. The analysis of related DNA sequences within plant families elucidates the evolutionary relationship and process involved in pest resistance development in plants. This information will aid in the understanding of $R$ genes and their proliferation within plant genomes.

Keywords Disease resistance $\cdot$ Resistance gene analog

\section{Introduction}

Plant resistance to pathogens is often governed by a specific interaction between a pathogen Avr (avirulence) gene locus and an allele of the corresponding plant disease resistance $(R)$ locus (Dangl and Jones 2001). This concept of matching an $R$ gene in the host and an Avr gene in the pathogen is referred to as the gene-for-gene hypothesis (Flor 1971). A number of plant genes conferring resistance to various plant pests have been isolated and characterized from a wide range of divergent species (Bent 1996; Hammond-Kosack and Jones 1997). Their products share 
striking structural similarities (Jones 1996), which led to the hypothesis that certain signaling events commonly occur during plant defense (Baker et al. 1997). Several $R$ gene classes have been identified on the basis of specific conserved functional domains. The most common belong to the leucine-rich repeat (LRR) family encoding proteins that contain an LRR domain near the $\mathrm{C}$ terminus. The LRR domain is highly variable in length and is thought to be involved in the recognition of the invading pathogen and/or the biochemical signals it produces. In addition to the LRR domain, the majority of the plant disease $R$ genes cloned to date (approximately 70\%) also encode a putative tripartite nucleotide-binding site (NBS) near the $\mathrm{N}$ terminus. The NBS region is characterized by the presence of several highly conserved domains regardless of the diversity of pathogens against which they act. The P-loop (kinase-1a) and the kinase- 2 domains are found in both adenosinetriphosphate- and guanosine-triphosphate-binding proteins (Saraste et al. 1990), while additional motifs found in the NBS region are the kinase-3a and the Gly-Leu-Pro-Leu (GLPL, also known as "hydrophobic domain"), a putative membrane spanning domain. NBS-LRR genes have also been shown to possess additional domains at their $\mathrm{N}$ terminus. A cytoplasmic signaling domain has been identified in several plant resistance genes that shares homology to the Drosophila Toll protein and the mammalian interleukin-1 receptor protein (TIF; Hammond-Kosack and Jones 1997). This motif has been given the acronym TIR and is speculated to be involved in cell signaling. Most of the non-TIR NBS-LRR $R$ genes have been reported to contain a coiled-coil motif or a leucine zipper motif proposed to facilitate protein interactions (Pan et al. 2000).

Previous approaches for identifying candidate genes controlling resistance against different pathogens have used highly saturated genetic maps for map-based cloning. The markers used for such maps generated polymorphic data based on restriction sites (restriction fragment length polymorphism [RFLP] and amplified fragment length polymorphism [AFLP]), random sequences (random amplified polymorphic DNA [RAPD]), and repetitive elements (simple sequence repeats). Such markers may not represent the segregating gene, and the likelihood of identifying a marker linked to the target gene is a function of the distribution of the marker type and location of the gene in the genome.

The conserved backbone of both TIR and non-TIR NBSLRR-class proteins has led to the development of polymerase chain reaction (PCR)-based strategies for isolating putative resistance gene analogs (RGAs). By the use of degenerate and/or specific primers targeted to the particular conserved amino acids in the NBS motifs at low annealing temperatures $\left(35^{\circ} \mathrm{C}\right.$ to $\left.55^{\circ} \mathrm{C}\right)$, a remarkable number of RGA sequences have been identified from many plant species including soybean [Glycine $\max (\mathrm{L}$.$) Merr.] (Kanazin et al.$ 1996; Yu et al. 1996), potato (Solanum tuberosum L.; Leister et al. 1996), barley (Hordeum vulgare L.) and rice (Oryza sativa L.; Leister et al. 1998), Arabidopsis thaliana (L.) Heynh. (Aarts et al. 1998), pea (Pisum sativum L.; Timmerman-Vaughan et al. 2000), grape (Vitis vinifera L.; Donald et al. 2002; Gaspero and Cipriani 2002), cotton (Gossypium spp.; Tan et al. 2003), tomato (Lycopersicum esculentum L.; Zhang et al. 2003), apple (Malus $\times$ domestica Borkh.; Baldi et al. 2004), and chestnut rose (Rosa roxburghii Tratt.; Xu et al. 2005). NBS sequences tend to be clustered in the genome, and isolated RGAs are frequently located at or near previously identified resistance loci or might even be parts of known $R$ genes (Kanazin et al. 1996; Yu et al. 1996; Aarts et al. 1998; Collins et al. 1998; Donald et al. 2002). Thus, molecular markers generated through this approach are useful to saturate regions of the genome where clusters of resistance genes are located and facilitate their map-based cloning.

Phytophthora species cause billions of dollars in annual losses to agricultural and forest species in the USA and worldwide (Erwin and Ribeiro 1996). Phytophthora root rot (PRR) of red raspberry is an economically important disease in nearly all temperate regions. The causal agent $P$. fragariae var. rubi Wilcox and Duncan (referred earlier as $P$. erythroseptica, P. erythroseptica var. erythroseptica, $P$. megasperma "type 2", and P. fragariae; Wilcox et al. 1999) is subterranean, soil persistent, and polycyclic. It is capable of rapidly spreading within the plant to cause severe root and crown rot in the absence of suppressing measures. Host resistance is the most effective control practice from both the environmental and economic perspective. Cultivars with known resistance include 'Latham', 'Newburgh', 'Durham', and 'Chief', while moderate resistance has been observed in 'Taylor', 'Haida', 'Chilcotin', and others (Barritt et al. 1979). Susceptible cultivars include 'Titan', 'Canby', 'Willamette', and 'Skeena' (Barritt et al. 1979; Wilcox et al. 1999). Unfortunately, many resistant cultivars are not commercially accepted in contrast to many moderately resistant and susceptible cultivars because of fruit quality requirements.

Analysis of the distributional extremes and quantitative trait loci (QTL) mapping of a backcross population $\left(\mathrm{B}_{1}\right)$ [('Titan' $\times$ 'Latham') $\times$ 'Titan'] using RAPD, AFLP, CAPS, and SCAR markers revealed two major genomic regions associated with PRR resistance in red raspberry (Pattison et al. 2007). A collection of RGA sequences from red raspberry would be an effective tool for the characterization of these regions and other disease-related genes (Leister et al. 1996, 1998; Yu et al. 1996). This study reports the identification and characterization of 75 RGAs developed through the use of degenerate primers designed to bind the P-loop, kinase-2, and the GLPL elements of the NBS 
region. Multiple and diverse RGAs are shown to exist in the red raspberry genome, and eight RGAs were mapped using a linkage map developed from the red raspberry cultivars 'Titan' and 'Latham'. To classify the Rubus gene fragments identified in this study, NBS-LRR sequences from Rosaceae that were publicly available were collected and analyzed. This allowed placement of the Rubus sequences in context with others identified within this plant family.

\section{Materials and methods}

Plant material, PCR amplification of RGA sequences

NBS-LRR sequences that had been previously identified in Rosaceae species and entered into GenBank were analyzed for the purpose of identifying suitable primers for the amplification of RGAs in red raspberry (Table 1). Seven degenerate primers from species in this family were utilized in this study (1) P-loop: 5'-GAATTCGGNGTNGGNAA GACAAC-3' (forward; Shen et al. 1998); (2) BP2f: 5'-GGN GGDGTDGGSAARAC-3' (forward; Baldi et al. 2004); (3) BP2r: 5'-GCTAGTGGCAMNCCWCC-3' (reverse; Baldi et al. 2004); (4) OLE 1121: 5'-GGWATGGGWGGW RTHGGWAARACHAC-3' (forward; Lee et al. 2003); (5) OLE 1122: 5'-ARNWYYTTVARDGCVARWGGVARWCC-3' (reverse; Lee et al. 2003); (6) DegRos_f: 5'-MDTKSBDR RRSSBDTTTWHRMM-3' (forward); (7) DegRos_r: 5'- RKDYWYDHMWHRDWKBWBMWK- 3' (reverse). Primers DegRos_f and DegRos_r were designed during the course of this study.

Genomic DNA from newly expanded leaves from the resistant cultivar 'Latham' was extracted for RGA amplification using the cetyl trimethylammonium bromide method as described by Pattison et al. (2007). PCRs were carried out in a total volume of $50 \mu \mathrm{l}$ with a 100 -ng template DNA and $0.4 \mu \mathrm{M}$ of each primer in $49.3 \mathrm{mM}$ Tris $-\mathrm{HCl}(\mathrm{pH}=8.3)$,
$2.5 \mathrm{mM} \mathrm{MgCl} 2,1 \mathrm{mM}$ tartrazine, $1.5 \%$ Ficoll, $125 \mu \mathrm{M}$ deoxynucleotide triphosphates, and $0.5 \mathrm{U} \mathrm{Taq}$ polymerase. PCRs were performed in a MJ Research PTC-100 thermocycler (Watertown, MA, USA) including initial denaturation for $2 \mathrm{~min}$ at $94^{\circ} \mathrm{C}$ followed by 40 cycles of $1 \mathrm{~min}$ at $94^{\circ} \mathrm{C}, 1 \mathrm{~min}$ at $50^{\circ} \mathrm{C}, 2 \mathrm{~min}$ at $72^{\circ} \mathrm{C}$, and a final extension at $72^{\circ} \mathrm{C}$ for $5 \mathrm{~min}$. Amplified DNA fragments were separated on a $2 \%$ TAE agarose gel and visualized by ethidium bromide staining.

Cloning and sequence analysis

DNA bands generated from the PCR reactions were excised from the gels and the DNA retrieved with a Sephaglas BandPrep Kit (Amersham Biosciences, Piscataway, NJ, USA) following the manufacturer's instructions. The eluted fragments were cloned using the pGEM-T Vector System (Promega, Madison, WI, USA). Recombinant plasmids were extracted with the QIAprep Spin Miniprep kit (Qiagen, Hilden, Germany), and the DNA was sequenced at the Cornell Sequencing Biotechnology Resource Center (Cornell University, Ithaca, NY, USA).

DNA and amino acid sequences were analyzed with the Laser Gene software package (DNASTAR, Madison, WI, USA) and the GeneDoc software, version 2.5.000 (www.psc.edu/biomed/genedoc). DNA similarity (basic local alignment search tool [BLAST]) searches were performed against nucleotide and protein sequence databases at the National Center for Biotechnology Information (NCBI: http://www.ncbi.nlm.nih.gov; Rehm 2001). Nucleotide sequences were conceptually translated using sequence utilities at the Baylor College of Medicine Search Launcher (http://searchlauncher.bcm.tmc.edu; Smith et al. 1996). In nine cases, amino acid frames were interrupted by one or two mis- or non-sense mutations. Correction to the original frame was done based on related published NBS-LRR amino acid sequences for the following nine

Table 1 Clones generated with the degenerate primers used for amplification of RGA sequences in red raspberry and number of fragments revealing homology to publicly available NBS-LRR sequences

\begin{tabular}{|c|c|c|c|c|c|c|c|}
\hline \multirow{2}{*}{$\begin{array}{l}\text { Primer } \\
\text { comb. }\end{array}$} & \multicolumn{2}{|c|}{ Degenerate primer } & \multirow{2}{*}{$\begin{array}{l}\text { Total number } \\
\text { of clones }\end{array}$} & \multirow{2}{*}{$\begin{array}{l}\text { NBS-LRR } \\
\text { homologous clones }\end{array}$} & \multirow[t]{2}{*}{ Group name } & \multirow[t]{2}{*}{ Class } & \multirow[t]{2}{*}{ GenBank ID } \\
\hline & Forward & Reverse & & & & & \\
\hline 1 & OLE1121 & OLE1122 & 48 & 43 & N4 & TIR-NBS-LRR & BV681230-271 \\
\hline 2 & $\mathrm{BP} 2 \mathrm{f}$ & $\mathrm{BP} 2 \mathrm{r}$ & 13 & 9 & N6 & non TIR-NBS-LRR & BV681272-280 \\
\hline 3 & DegRos_f & OLE1121 & 16 & 5 & N9 & non TIR-NBS-LRR & BV681281-285 \\
\hline 4 & OLE1121 & DegRos_r & 15 & 9 & N14 & non TIR-NBS-LRR & BV681287-296 \\
\hline 5 & $\mathrm{BP} 2 \mathrm{f}$ & DegRos_r & 16 & 1 & N16 & non TIR-NBS-LRR & BV681297 \\
\hline 6 & OLE1121 & $\mathrm{BP} 2 \mathrm{r}$ & 13 & 5 & N19 & non TIR-NBS-LRR & BV681298-302 \\
\hline 7 & P-loop & OLE1122 & 12 & 3 & $\mathrm{~N} 23$ & TIR-NBS-LRR & BV681303-305 \\
\hline Total & & & 133 & 75 & & & \\
\hline
\end{tabular}


sequences: 15_Ri_19-7, 20_Ri_4-1, 23_Ri_4-12, 34_Ri_423, 46 Ri 4-40, 49 Ri_4-53, 50 Ri-4-54, 65 Ri_6-31, and 72 Ri $9-11$ (Supplemental Table S1).

All public NBS-LRR amino acid fragments from Rosaceae available at the time of analysis were downloaded from the NCBI GenBank (http://www.ncbi.nlm.nih.gov; Supplemental Table S1). These sequences were aligned together with the conceptually translated Rubus fragments generated in this study, using hidden Markov models with the Sequence Alignment and Modeling Software System (SAM-T2K; Karplus et al. 1998) and formatted for analysis with the Phylip phylogenetic inference package (Supplemental File "Samuelian et al Rosa NBS-LRR S2.phy"). Seqboot in the Phylip package (Felsenstein 2006) was used to generate 1,000 bootstraps of the dataset, and Protdist was used to construct 1,000 bootstrapping distance matrices using the Jones-Taylor-Thornton calculation, with one category of substitution rates. A neighbor-joining tree of the 1,000 bootstraps was constructed (jumbling the sequence input order twice) and a majority-rule consensus tree determined.

\section{Marker development and RGAs mapping}

Primers specific to the cloned raspberry RGA sequences were designed utilizing a manual analysis of the clone sequences to develop PCR-based markers for genetic mapping. Three criteria were followed for primer design: (1) $50-70 \%$ guanine-cytosine (GC) content, (2) predominant GC content at the $3^{\prime}$ end, and (3) a primer length of 20 to $24 \mathrm{bp}$ to ensure similar melting temperatures (Table 2). The oligonucleotides were synthesized by MWG-Biotech (High Point, NC, USA). Each primer pair was tested with genomic DNA from 'Titan', 'Latham', and the $F_{1}$ parent from the previously mapped $\mathrm{B}_{1}$ population (Pattison et al. 2007) to identify polymorphisms. Amplification was performed under the same conditions already described, only with an annealing temperature of $62{ }^{\circ} \mathrm{C}$ instead of $50{ }^{\circ} \mathrm{C}$. Markers generated using this technique are referred to as sequence characterized amplified regions (SCARs; Paran and Michelmore 1993). When a polymorphism between the parents was not identified based on primer site annealing, a restriction digestion was performed using $20 \mu$ of each PCR reaction to identify sequence differences resulting in restriction site polymorphisms. Polymorphisms identified through PCR amplification with specific primers followed by restriction digestion are referred as to cleaved amplified polymorphic sequence (CAPS) markers (Konieczny and Ausubel 1993). PCR products and their digestions were visualized on 3\% MetaPhor agarose gels (Cambrex, Rockland, ME, USA) stained with ethidium bromide. The specific primers for the development of the SCARs and the specific primers together with the restriction enzymes used for the development of the CAPS markers are shown in Table 2.

Mapping of markers derived from RGAs was performed using 68 individuals from a $\mathrm{B}_{1}$ population previously screened for PRR resistance (Pattison et al. 2007). Identified polymorphisms were mapped using JoinMap 3.0 ${ }^{\circledR}$ (Van Oijen and Voorrips 2001) with linkage groups assigned at a minimum logarithm of the odds of 3.0.

\section{Results}

Cloning of RGAs and sequence analysis

All 12 possible primer combinations between the forward and reverse primers described were investigated. From each primer combination, approximately 15 clones were sequenced. Searches of the GenBank database using the BLASTN and the BLASTX algorithms showed that clones generated with seven of the primer combinations revealed homology to

Table 2 Specific primers based on cloned RGA sequences from 'Latham' red raspberry that generated polymorphic SCAR and CAPS markers in a ('Titan $\times$ 'Latham') $\times$ 'Titan' $B_{1}$ red raspberry population with the corresponding restriction enzyme for the CAPS markers

\begin{tabular}{llllll}
\hline RGA clone & Primers & & $\begin{array}{l}\text { Enzyme revealing } \\
\text { polymorphism }\end{array}$ & LG (Fig. 1) & Marker type \\
\cline { 2 - 5 } & Forward & Reverse & & \\
\hline 55_Ri_4-6 & AAAACTACCATCGCCACAGCTG & AGCACACTCTATGGCAAGACC & & Dominant \\
23_Ri_4-12 & AGAATCGACGGTACTCTGTCGA & TTCACAAAGAAGGGTGAGACAG & AluI & 2 & Co-dominant \\
27_Ri_4-16 & ACCTTGGTAAAGCAAGCGTACG & TTCCCCTGAAATGTCTTCCTGC & MseI & 2 & Co-dominant \\
32_Ri_4-20 & CTGCACGGCTTGAGAGATGATC & TTCGGGAACCAAGTACGTATGC & & Co-dominant \\
42_Ri_4-34 & AAGACTACCATCGCTAGAGCTG & AGTTGAACAGCTTCACCATCGC & EcoRI & 6 & Dominant \\
58_Ri_4-62 & TTGGCAGTTTGAACACTGTTGC & GACACGCCTTGAGAGATGATTG & MseI & 4 & Dominant \\
70_Ri_6-7 & GATGAGGTGGTTATGGTACTCG & CCACACTTCTCAGCTACTTTGG & TaqI & Dominant \\
67_Ri_6-33 & GATGTGATTATCCTACTAGATG & CATCTTTCGGCTACTTTGATTG & MseI & 1 & Dominant \\
9_Ri_14-36 & GACGGTAGCTTAACCATAGAGC & AAGACTACCCTTGCTAAGCTCG & TaqI & 1 & Dominant \\
\hline
\end{tabular}




\section{LG1}
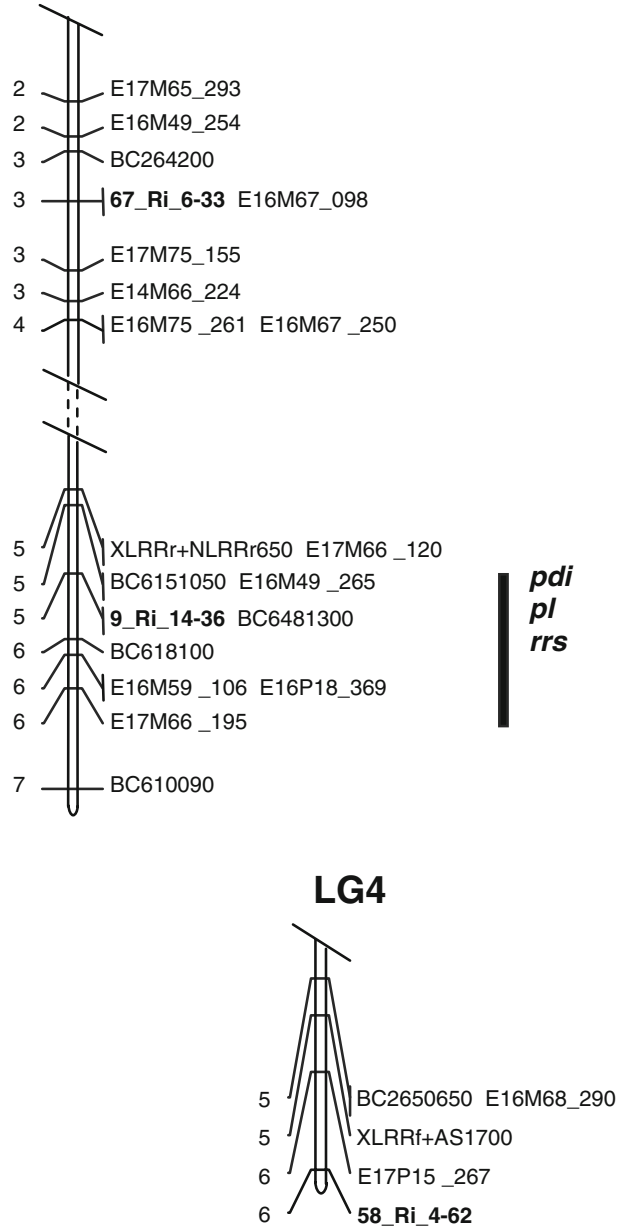

Fig. 1 Genetic linkage map showing the position of the RGA loci (in bold letters) on red raspberry linkage groups. Mapping was done on a ('Titan' $\times$ 'Latham') $\times$ 'Titan' $B_{1}$ population. Relative locations of putative QTLs for plant disease index $(p d i)$, petiole lesion $(p l)$, and
LG2
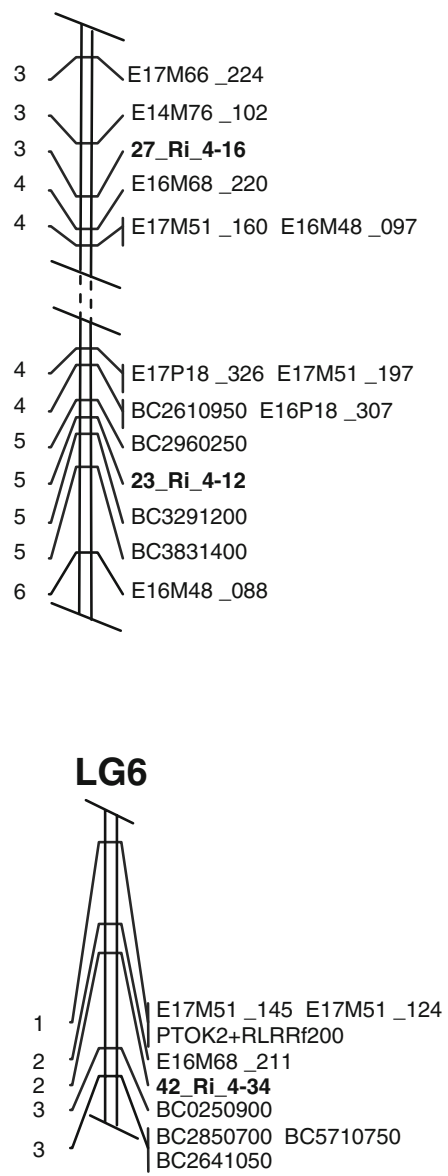

LG3

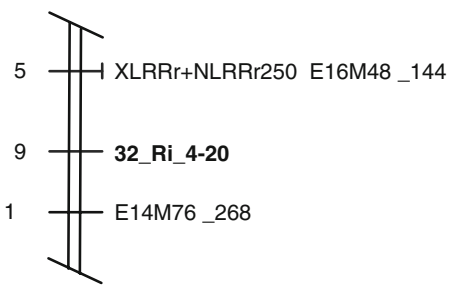

\section{LG7}

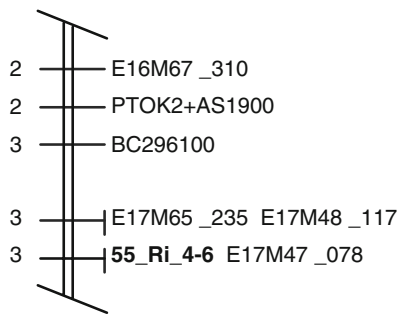

root regeneration score (rrs) are shown as vertical bars on the right of the linkage group and were assigned by Pattison et al. (2007). The marker distances are indicated in centimolar calculated in Kosambi units (Lander et al. 1987)

Marker development and linkage mapping

NBS-LRR sequences (Table 1). Fragments cloned from the remaining five primer combinations did not reveal homology to NBS-LRR sequences and were excluded from further analysis. Approximately $93 \%$ of the clones generated with primer pair OLE1121/OLE1122 showed strong overlapping similarity to RGA sequences. Therefore, an additional set of 33 clones from that group was sequenced bringing the total number of clones analyzed for NBS-LRR homologies to 133 (Table 1). BLASTX searches of the SwissProt and GenBank NR databases revealed that 62 of them were highly homologous to house-keeping genes or did not show homology to any sequences in the database and were excluded from further analysis. The remaining 75 sequences with sizes between 197 and 702 bp were highly similar to RGA sequences cloned from other plant species using similar PCR-based approaches.
Specific primers were designed for each RGA sequence (Table 2) to identify polymorphic markers that could be placed on a red raspberry genetic linkage map (Pattison et al. 2007). The map was developed using a segregating $B_{1}$ population that was screened for resistance to $P$. fragariae var. rubi and was analyzed for QTL associated with resistance (Pattison et al. 2007). When genomic DNA of 'Titan', 'Latham', and $\mathrm{F}_{1}$ parent of the mapping population were amplified, a dominant presence/absence polymorphism was revealed for two RGAs, 55 Ri 4-6 and 32 Ri 4-20 (Table 2). A single band of the expected size was observed for all other RGA fragments. To identify polymorphisms in the monomorphic products, a set of restriction enzymes (mainly four basepair cutters) was 
utilized to detect restriction site polymorphisms. Polymorphisms were identified in seven of the RGAs, thus allowing the development of CAPS markers. These markers were screened in the mapping population for placement on the map. The RGA markers were present on six of the seven linkage groups in red raspberry with no clustering seen (Fig. 1). The RGA fragment 9_Ri_14-36 was mapped on LG1 within the first putative QTL for PRR resistance (Pattison et al. 2007; Fig. 1), and 67_Ri_6-33 was mapped elsewhere on the same linkage group. No NBS-LRR loci were placed on LG5 where the second major QTL for PRR was positioned. Two sequences, 23_Ri_4-12 and 27_Ri_4-16, were mapped on LG2, and the remaining four sequences 32_Ri_4-20, 58_Ri_4-62, 42_Ri_4-34, and 55_Ri_4-6 on linkage groups $3,4,6$, and 7 , respectively (Fig. 1). Marker 70_Ri_6-7 could not be placed on the genetic linkage map.

\section{Classification of Rosaceae RGAs}

Additional published NBS-LRR protein fragments from other Rosaceae were downloaded from GenBank, conceptually translated, and aligned with the 75 Rubus sequences obtained in this study. These include 16 Fragaria (Martinez Zamora et al. 2004), 76 Malus (Lee et al. 2003; Lee and Lee 2003, 2006; Baldi et al. 2004; Varshochi 2006), 8 Prunus (Lalli et al. 2005; Liang et al. 2005), 11 Pyrus (Afunian et al. 2006), and 78 Rosa (Hattendorf 2005; Hattendorf and Debener 2007; Xu et al. 2005). Six additional Prunus consensus NBS-LRR fragments representing sequences that have not been deposited in the public domain were added (Soriano et al. 2005; Supplemental Table S1). Sequences from some related studies for peach (Liang et al. 2005) and apple (Calenge et al. 2005) were not available.
Fig. 2 Alignment of conceptually translated Rubus TIR sequences. The RNBS-A-TIR motif is characteristic of plant TIR-NBS-LRR RGAs. Identical residues with $50 \%$ or greater frequency in a column have a dark grey background. Similar residues with $50 \%$ or greater frequency have a light grey background

\begin{tabular}{|c|c|}
\hline & RNBS-A-TIR \\
\hline & ------1 \\
\hline $\begin{array}{l}20-\mathrm{RI}^{-}-1 \\
34 \mathrm{Ri} \\
-4-23\end{array}$ & $\begin{array}{l}\text { GMGGVGKITLAKLVFERISHP } \\
\text { GMGGVGKTTLAKVVFERIS -I }\end{array}$ \\
\hline $17 \mathrm{Ri} 23-1$ & J-FLLNVREVSAKHG - - SLVDLQKQLLSPILKEN \\
\hline $57 \mathrm{Ri}^{-4-61}$ & - FVSYVRN-NEEKS - - GLVHLQETLISRILG-K \\
\hline $16 \mathrm{Ri} 19-9$ & - FLADVRETMQK-D - - GKVSLQESLLSDISKTT \\
\hline $44 \mathrm{Ri}^{-4}-37$ & SFLENIREVSEQSN - - GLLKLQKQLINDILTGR \\
\hline $60 \mathrm{Ri} 4-8$ & S-YLENIREVSEQPN - - GLLRLQKQLLNDI ITGS \\
\hline $21 \mathrm{Ri} 4-1 \overline{0}$ & - FLENIREVSEQAN - - GLVQLQKQLIYDILNGK \\
\hline $19 \mathrm{Ri} 23-9$ & -EFGVGKTTIAKVVYNSNFR-RFEI \\
\hline $36 \mathrm{Ri} 4-25$ & - - GLVQLQRQFISDILN-R \\
\hline $29^{-} \mathrm{Ri}^{-4}-18$ & S-FLENIREISENPN - - GLVQLQRQLLADILN-R \\
\hline $61 \mathrm{Ri} 4-9$ & -FLNNVREVSAERHGTGIVTLQEKLLSDAQMG- \\
\hline 18_Ri_23-6 & - FLDNVKEEFLTKH - - - - KVTEALLSKILKVN \\
\hline 45_Ri_4-4 & -FLDNVKEEFLTKN - - - - KVTEALLSKILKVN \\
\hline $55 \mathrm{Ri}-4-6$ & - FLENIKDRFRATNG- -DIHTLEELLSRMLKEE \\
\hline $39 \mathrm{Ri}^{-4}-29$ & FLENVKEGFKNNG - - -AIHMQEELLSR IFDKR \\
\hline $22 \mathrm{Ri}^{-4-11}$ & GMGGVGKTTIAKAVYDEIAY \\
\hline $56 \mathrm{Ri}^{-4}-60$ & GMGGIGKTTIAKAVYDE \\
\hline $31-\mathrm{Ri} 4-2$ & GMGGIGKTTIAKAVYDEI \\
\hline $35 \mathrm{Ri} 4-24$ & GMGGVGKTTIAKAVYDE \\
\hline $43 \mathrm{Ri}^{-4}-36$ & GMGGVGKTTIAKAVFDE \\
\hline $48 \mathrm{Ri}-4-5$ & - KAQIQEDLLSRILKDK \\
\hline $54 \mathrm{Ri}^{-4}-59$ & GMGGVGKTTI \\
\hline $41 \mathrm{Ri}^{-4}-33$ & GMGGVGKTTIAKAFYDE \\
\hline $37 \mathrm{Ri}^{-4}-26$ & GMGGVGKTTIARAVYDE \\
\hline $38 \mathrm{Ri}-4-28$ & GMGGVGKTTIARAVYEKL \\
\hline $42 \mathrm{Ri} 4-34$ & - GIQMQEELLCRILMEK \\
\hline $47 \mathrm{Ri}^{-4-41}$ & - - GIQMQEELLCRILMEK \\
\hline $23 \mathrm{Ri}^{-4}-12$ & GMGGIGKTTVARAVYDKIF \\
\hline $46 \mathrm{Ri} 4-40$ & GMGGVGKTTVARAVYDKI \\
\hline $40 \mathrm{Ri} 4-3$ & GMGGVGKTTIASVVYDEIAS- \\
\hline $52 \mathrm{Ri}^{-4}-57$ & FLENITGGFTKKG - - ETQMRKELLSRIYSDK \\
\hline $32 \mathrm{Ri} 4-20$ & GMGGIGKTTIATEVYDEIRS - QFSHCY - FLPNVKEGFGNQV - - - - RMQEQLLSGILKKE \\
\hline 49_Ri_4-53 & GMGGIGKTTIAKAVYDKIAY \\
\hline $50 \mathrm{Ri}^{-4}-54$ & - - EAQMRGEFLSEILKDK \\
\hline $58 \mathrm{Ri}^{-4}-62$ & GMGGVGKTTIAKAVYDE \\
\hline 28_Ri_4-17 & GMGGVGKTTITRAVYDE \\
\hline & \\
\hline
\end{tabular}


Fig. 2 (continued)

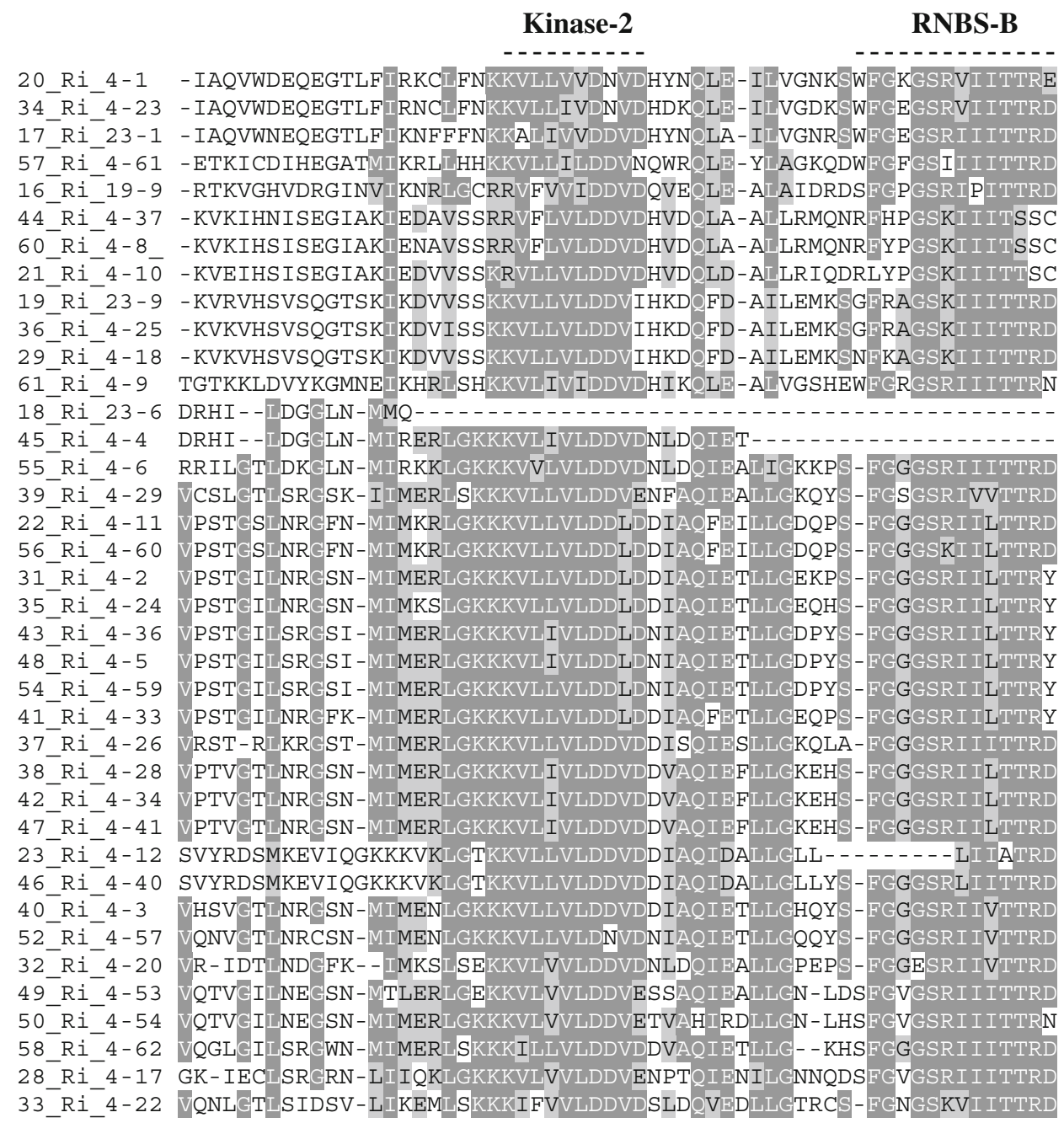

\begin{tabular}{|c|c|}
\hline & $\mathrm{C}$ \\
\hline 0_Ri_4-1 & ERLIIEHD - - - IERSF- - KVDGINDSTA-LELFSHNAFRKI \\
\hline $4 \mathrm{Ri}^{-} 4-23$ & ERLIIKHD- \\
\hline 7_Ri_23-1 & ERLIEHD - - - IERSFTVELEGLNAST \\
\hline 7_Ri_- $4-61$ & EHLIVKRG - - -VTRRF - - QVQGLHTDI \\
\hline 16_Ri_19-9 & GHLIKQLG - - - VDAIYR - -AREMNEE \\
\hline 44_Ri_4-37 & AGLIEA-HC-QFVKVHD--VRIIDN \\
\hline 60_Ri_4-8 & AGLLEA-HC-QFVKVHE--VRILDP \\
\hline $21{ }^{-} \mathrm{Ri}_{-}^{-} 4-1 \overline{0}$ & - AALFSWHAFGQD - -HPIHSYWDHSKRLIDHC \\
\hline 19-Ri_23-9 & S-LELFSMHAFGQV- - HPIESYMEVSKKVMSHC \\
\hline 36_Ri_4-25 & LELFSMHAFGQV - - HPIESYMEVSKKVMSHC \\
\hline 29_Ri_4-18 & AGLLTA - LQ - VVDYVHM - - VETLSDNES - LELFSRHAFRQV - HPI KGYTQLSQQVVSHC \\
\hline 61_Ri_4-9 & EHLLTTHGVD - - - VIYE- -AQKLRTDEA-LKLFSCKAFKNRNHDDKEKYMVLSDKFVKYT \\
\hline $\mathrm{B}^{-} 23-$ & \\
\hline
\end{tabular}

Multiple alignments showed that the similarity was especially high at various NBS motifs: P-loop, kinase-2, RNBS-B, and GLPL. The TIR and non-TIR RNBS-A motifs are clearly visible (Figs. 2 and 3). The full alignment of all 270 amino acid sequences is available in format suitable for input to Phylip as supplemental data (Supplemental File "Samuelian et al Rosa NBS-LRR S2.phy").
Amino acid distances between the Rubus RGA fragments and those from other Rosaceae ranged from 0.1303 to 9.5287. Among the entire dataset, the range of amino acid distances was 0.0058 to 9.2587 .

The resulting neighbor-joining tree displays well-supported classification of the Rosaceae NBS-LRR sequences both between TIR and non-TIR and within each category. The 
Fig. 2 (continued)

$45 \mathrm{Ri} 4-4$ 55 Ri-4-6 KHLIA-GY-- - - VMYE--PKLFTDEKA-LELFRQYAFRTK- - PPSGNYDGLLGLAIECA 39_Ri_4-29 IOSLSGVN - - - -ARYS - - PMFLSDDEA-LELFMQYAFRTN - KPTREYDPLSRRAVEYA 22_Ri_4-11 KOSLSGVEY - - - QLYN- - PKCLSYDKA -HELFMKYAFRTK- - KPSGEYDHLSRRAIKYA 56_Ri_4-60 KOSLSGVEY-- - -QLYN--PKCLSYDKA-HELFMKYAFRTK- - KPSGEYDHLSRCAIKYA 31_Ri_4-2 IOSLSGVKY - - - RLYK- - LKCLSYYKA - HELFMKYAFRTN - - KPSGEYDHLSRRAIKYA 35_Ri_4-24 IOSLSGVEY - - - RLYM- - PTCLSYDKA-HELFMKYAFRTN - -KPSGEYVHLSRRAIEYA 43_Ri_4-36 IOSFSGVEY----RLYK- - PKCLSYDKA-HKLFMKYAFRTN- - KPSGEYDHLPRRAIEYA 48_Ri_4-5 IOSFSGVEY-- - -RLYK- - PKCLSYDKA-HKLFMKYAFRRN- - KPSGEYNHLPRRAIEYA 54_Ri_4-59 IOSFSGVEY-- - -RLYK- - PKCLSYDKA-RKLFMKYAFRTN - KPSGEYNHLPRRAIEYA $41^{-} \mathrm{Ri}^{-} 4-33$ IOSLSRVEY - - - RLYK- - PKCLSYDKA - YELFIKYAFRTN- -KPSGEYYHLSRCAIEYA 37_Ri_4-26 IQSLSGVEY-- - -VMYK- -PKCLRYSEA-YELFRQYAFRTN- -EPSAEFDHLSRCAIEYA 38 Ri $4-28$ TQLIRRVD- - - - -QIYK- -PNLLSDGEA-VQLFRQYA

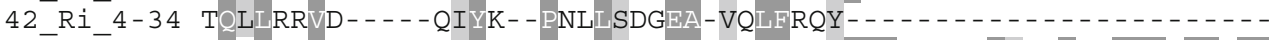
47_Ri_4-41 TOSLRRVD-- - - -QIYK- - PNLISDGEA-VQLFRQYAFRTN - KPSGQYDNLSRCAIKYA 23_Ri_4-12 KOILSGVKA- - - KTYC- - PGLIRPKEALIVLFRQFVFRKI - -NPSTEYRRFSRHAIELA 46_Ri_4-40 KOILSGVNA - - - KTYC- - PGLLRPKEALLVLFRQFVFRKI - -NPSTEYRRFSRHAIELA 40-Ri-4-3 QQILSGVNA - - - ITYC- - PGLLRPKEA-IVLFRKFAFRTI - - DPTTEYRRLSRYAIEFA 52_Ri_4-57 EQILSAVDA - - -SKYF- - PSLLRPREA-IILFRKIAFRTI - -DPSTEYRRLSRHAIEFA 32_Ri_4-20 SRILNGFE- - - - - - IYK- -AELIIDGNA-GKLFSQYAFKTN - - KP SGEYDHLSSRAVEYA 49_Ri_4-53 KOSLSGVH- - - - ELYE- - PKHLSHDEA-HQLFMKYAFRKN- -QPTGDYNHLSRRAINYA 50_Ri_4-54 KOSLSGVN-- - - EFFE--PKALSGDEA-YELFMKHAFNTK- -QLTGDYNHLSRRAINYA 58_Ri_4-62 KOSLSGVH- - - - -ELYE- -PKHLSHDEA-HELFMKYAFRKN - - QPTRDYNHLSRRVIEYA 28_Ri_4-17 KQSLSGVP - - - - ELYK- - PEKLSGEEA-DELFMKHAFRKN - -QPTEDYNHLSWRAREYA 33_Ri_4-22 RSLLSESK- - - - -MYD- -PDFMEKKEA-LELFRKYA- - - - -KPSTQYDHLLSHAINYA

\section{GLPL}

20_Ri_4-1 KGLPLALKE34-Ri_4-23 KGLPLRLQSL 17_Ri_23-1 KGLPFALKD57_Ri_4-61 KGLPLALKN16_Ri_19-9 GGLPL-..-. 44_Ri_4-37 AGFPLALKV 60_Ri_4-8_AGLPL-.-.21 Ri $4-1 \overline{0}$ GGLPLAFIKD19-Ri_23-9 EGLPFALKI36_Ri_4-25 EGLPFALKK$29^{-} \mathrm{Ri}^{-} 4-18$ EGLPLALKI 61_Ri_4-9 NGLPLALKV$18 \mathrm{Ri} 23-6 \ldots$ $45{ }^{-} \mathrm{Ri}^{-} 4-4 \quad \ldots \ldots \ldots$ 55_Ri_4-6 HGLPLALKE 39-Ri_4-29 QGLPFALKN22_Ri_4-11 QGLPFALKI56 ${ }^{-}{ }^{-} 4-60$ QGLPFALKD31_Ri_4-2 QGLPFAFKE35 Ri 4-24 OGLPLALKN43-Ri_4-36 QGLPFAFIK48_Ri_4-5 QGLPLALKV 54_Ri_4-59 QGLPLALKM41_Ri_4-33 QGLPLALKD37_Ri_4-26 HGLPLAFKV38_Ri_4-28 -....-. $42-\mathrm{Ri}^{-} 4-34$-....... 47_Ri_4-41 QGLPFALKN-

23 Ri 4-12 QGLPLALKN46_Ri_4-40 QGLPLALKV40_Ri_4-3 QGLPFALKE52_Ri_4-57 QGLPLALKI 32_Ri_4-20 QGLPLALIKI49-Ri-4-53 RGLPLALKE50_Ri_4-54 QGLPLALKK58 ${ }^{-}{ }^{-} 4-62$ QGLPFALKV28_Ri_4-17 KGLPLALKN33_Ri_4-22 QGLPLALKI- 
Fig. 3 Alignment of conceptually translated Rubus non-TIR sequences. The RNBS-A-non-TIR motif is characteristic of plant non-TIR-NBS-LRR RGAs. Identical residues with $50 \%$ or greater frequency in a column have a dark grey background. Similar residues with $50 \%$ or greater frequency have a light grey background
P-loop

11_Ri_16-2 75 Ri $9-37$ 9_Ri_ $\overline{1} 4-36$ 74 Ri $9-32$ 73-Ri-9-30 26 Ri $4-15$ $13{ }^{-} \mathrm{Ri}^{-19-2}$ 30_Ri_4-19 12 Ri 19-2 15_Ri_19-7 65 $\mathrm{Ri} 6-31$ 64_Ri_6-2 69- $\mathrm{Ri}^{-6-5}$ 62-Ri 6-1 67 Ri $6-33$ 68 $\mathrm{Ri}^{-6-35}$ 66 Ri $6-32$ $70^{-} \mathrm{Ri}^{-} 6-7$ 63 $\mathrm{Ri}^{-6-10}$ 14 Ri $19-3$ $25 \mathrm{Ri}^{-} 4-14$ 7 Ri $14-33$ 71_Ri_9-1 1 Ri 14-1 3-Ri-14-20 2.Ri_14-2 5-Ri $14-30$ 4_Ri_14-23 10_Rí_14-5 72_Ri_9-11 $6 \overline{\mathrm{R}} \mathrm{i} \overline{1} 4-31$ 59_Ri_4-7 51 Ri 4-56 53 Ri $4-58$ 24 Ri_4-13 $27^{-} \mathrm{Ri}^{-} 4-16$ 8_Ri_14-35
RNBS-A-non-TIR

GGVGKTTLARQVVYHHE- -EVKRHFECFA-WVSISQ - - - - - EYQVRDVLERIYVK GMGGVGKTTLAKDVFNDA- - -ATEQFSPKG-WVSVS - - - - - - - DDFDLLRVATAILES GMGGVGKTTLAKLVYNDE- - KVTRYFDLRA-WVCVS-- - - - - -DDFDVVKITQKIYMS GMGGIGKTTLAQLVYNDE- -KVTRHFDLRA-WVCVS- - - - - - -DDFDVVKITRTIYQK GMGGIGKTTLAQLVYNDE- - KVTRYFQDRA-WVCVS- - - - - - -DDFDVVKVTRTIYMS GMGGVGKTTLAQVVYNDT - -RVKEEFDLRA-WVCVS- - - - - - DDFDVLRITQAVYAS GMGGVGKTTLSQLAYNDE- - RVIQHFDVRM-WTFVS - - - - - - - DDFNIKKIMKSIIES GMGGVGKTTLAKYVYNDE - -RVVMHFEMRM-WAYVSA - - - - - - -VDFDICRLTKEIPSS -MGGVGKTTVAKS I FHDA - - KIHAHFDERL - WVCVS - - . - . - - TPFKIKSVLRGVLES GMGGVGKTTLEKEVYKQAT-EDKTLEDDVVILLDVKK- - - - - - - NPDVEGIQKKIVEK - - GGVGKTMLEKEVYKQAT - EDKTLFDDVVILLDVKKK- - - - - - - - NPDVEGIQKKIVEK - -GGVGKTTLVKEIYKQAS - EDKKLFDDVVILLDVKK- - - - - - - NPDLEAIQKKIIEK - -GGVGKTTLVKEIYKQAS - EDKKLFDDVVILLDVKK - - - - - - - - NPDLEAIQKKI IEK - - GGVGKTTLVKEIYKQAS - EDKKSFDNVVILLDVKK- - - - - - - - NPDLEAIQKIIVEK - - GGVGKTTLVKEIYKQAS - EDKKLFDDVI ILLDVKK - - - - - - - - DPNLEAIQKVTVEK - - GGVGKTTLVKEIYKQAS - EDKKLEDDVIIVLDVKK - - - - - - - - DPNLEAIQKIIVDK - -GGVGKTTLIKEVYRQSN-GDEKLLDKVAMVLDLKQ - - - - - - - NPSIERIQKEIIEK - -GGVGKTTLVKEIYKKTK-KDEKLFDEVVMVLDLKQ - - - - - - - - NPTIERIQKEIAEK - -GGVGKTTLAKEVYRQAN-E-KKLEDGVVIVVDMKNYADSERIQKENYIERIQKEIAEK - -GGVGKTTLVKEIGAKAD - EVNLFDDVAF - -AEFTQ - - - - - - - EPDLVKIQGKIAKD GMGGVGKTTMVKHVGSQAQ-NNEIFHHVIMAVVLVSQ - - - - - - - TPDLRRIQGIFADM GMGGVGKTTMVEHVGAQAK-YKGIFLYVIK - -AVVTQ - - - - - - - - SPNFWKIQGTLADM GMGGVGKTTMVEHVGAQAK-NKGIFLYVIK- -AVVTQ - - - - - - - SPNFWKI QGTLADM GMGGVGKTTMVEHVGAQAK-NKGIFLYVIK- -AVVTQ - - - - - - -SPNFWKI QGTLADM GMGGIGKTTMVEHVGAQAK-NKGIFLYVIK- -AVVTQ - - - - - - - SPNFWKIQGTLADM GMGGIGKTTMVKHVAAQAR - KYGI FNQVIM- - AVVSQ - - - - - - - SPDWRKIQGALADL GMGGI GKTTMVKHVAAQAR - RYGIFNQVIM - - AVVSQ - - - - - - - SPDWRKIQGALADL GMGGIGKTTMVDHVGAQAK-NKGIFQHVTK- -AVVSQ - - - - - - - NPNFWKIQGTLADL GMGGVGKTTMVDHVGAQAK-NKGIFQHVTK- -AVVSQ - - - - - - - NPNFWKIQGTLADL IMGGIGKTTMADHVGAQAK-NKGIFQHVTK- -AVVSQ - - - - - - - - NPNFRKIOGTLADL GMGGIGKTTMVEHAAALAK-NKGIFHHVIK- -AVVSQ - - - - - - - NPNFWKIQGTLADL GMGGVGKTTMVEHVAALTK-NKGIFHHVIK- -VVVSQ - - - - - - - NPNFEKIQGTLADL GMGGVGKTTIAKKVFTDTQ-VISHFN - - KMIWVSVSQ- - - - - - - NFSAQRIVKCMLEK GMGGVGKTTIAKKVFTDTQ-VISHFN - -KMIWVSVSQ - - - - - - - NFSAQRIVKGMLEK GMGGIGKTTLVKQVYEDP - -KVQKRFKVHA-WITVSR - - - - - - - - SFKINQLLRHMIKK GMGGIGKTTLVKQAYEDP - -NVQKRFKVHA-WITVSR - - - - - - - TFKINQLLRHMIKK GMGGVGKTTIGRVESLDLHNPYLDGLDSDALVGEIN- - - - - - - - PSLLDLKDLIYLD

\begin{tabular}{|c|c|}
\hline & Kinase-2 \\
\hline i_16-2 & -ERKCLIVLDDIWWKIET-- - - - -WD \\
\hline$i_{-}^{-} 9-37$ & - -KKFFIVLDDVWDTCN-- -YGQWT \\
\hline $\bar{R} i \_\overline{1} 4-36$ & KEALTG- - KKFLFVLDDVWNENS - - - AD̃WD \\
\hline $4 \mathrm{R} \overline{\mathrm{i}} 9-32$ & - - KKFLFVLDDVWNENH - - - -ADWD \\
\hline 73_Ri_9-30 & KEALTG - - KKFLFVLDDVWNENY - - - DYWD \\
\hline $6^{-} \mathrm{Ri}^{-} 4-15$ & KEALAR - -KKFLIVLDDVWNENY - - - - SDWD \\
\hline $13^{-} \mathrm{Ri}^{-} 19-2$ & WHLLHH - -KRYLLVLDDVWTEDQ - - - - DDWD \\
\hline $30 \mathrm{Ri} 4-19$ & LREALKD- -NKFLLVLDDVWNEDR - - - -MKW- \\
\hline $12 \mathrm{Ri} 19-2$ & LKSKNAAVQT - - - - - - KEAMCGV - - - IKEELQG - -KRYLLVLDDVWNEES - - - DKWD \\
\hline $15 \mathrm{Ri} 19-7$ & LGMDILD - - - - _ - - HNETIDGRASRICARIQG - -KKILVILDDVQEK - - - - - IDME \\
\hline 65_Ri-6-31 & LGMDILD - - - - - - - - HNETIDGRASRICARIQG - -KKILVILDDVQEK- - - - - IDME \\
\hline 64_Ri_6-2 & LGMKIE - - - - - - - - PDETIEGRAIRLCGKIQD - KKIIVILDDVEEK- - - - - IDLE \\
\hline
\end{tabular}

TIR sequences clustered separately from the non-TIR sequences with a $75.8 \%$ bootstrap value (Fig. $4 \mathrm{a}$ and $\mathrm{b}$ ). Within the TIR sequences, there were 11 distinct clusters with bootstrap values of more than $50 \%$ containing sequences from multiple genera (Fig. 4a). There were also 11 such clusters among the non-TIR sequences. Nine of these multigenus clusters have a bootstrap value of more than $75 \%$, and seven have a bootstrap value of more than $90 \%$. Four of the mapped Rubus sequences clustered near the TIR I group, while three others were spread between the non-TIR groups. Only one mapped sequence is in a terminal multiple-genus group; 67_Ri_6-33, in non-TIR group VIII. Among all the Rubus sequences isolated in this study, there were representatives among groups TIR I, TIR III, TIR V, TIR X, and TIR XI and non-TIR II, non-TIR IV, non-TIR VII, non-TIR VIII (10 of the 11 members), non-TIR IX, and non-TIR XI (13 of the 14 members; Fig. 4b). A more detailed illustration with color coding for each genus is provided in Supplemental Fig. S3. 
Fig. 3 (continued)

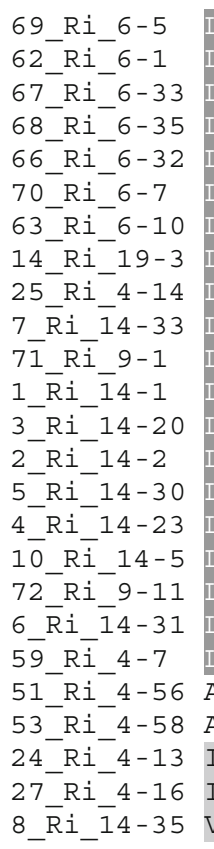

\begin{tabular}{|c|c|}
\hline & \\
\hline & SKSKILLTTRK - \\
\hline $\mathrm{Ri}^{-} 9-$ & SFRVGAA - GSKI IVTTRDANVAF \\
\hline $\bar{i}-\overline{1} 4-36$ & $1-$ \\
\hline Ri $\bar{i}_{-} 9-32$ & KIIVTT \\
\hline Ri_9-30 & IIVTTF \\
\hline i_4-15 & NILVTTR \\
\hline i_19-2 & KIIVTSR \\
\hline i_4-19 & $-I \mathrm{PFCTQC}$ \\
\hline Ri_19-2 & D-LRNCLLRGTDTR \\
\hline Ri_19-7 & VVGLPRL- - - - A \\
\hline -Ri_6-31 & CKILLTCRTREVLSIDKMCA-EKVF \\
\hline Ri_6-2 & F- -DEMRA-DKVVC \\
\hline -Ri_6-5 & -DEMCV-DKVFR \\
\hline _Ri_6-1 & F- -DETRA-DKVIQ \\
\hline -Ri_6-33 & AVGLPRL - - \\
\hline _Ri_6-35 & AVGLPRQ - - - - \\
\hline -Ri_6-32 & LS - RDMIGT-QKEFI \\
\hline -Ri_6-7 & AVGLPRM- - - - - E \\
\hline i__6-10 & LY - SKMGT-QKEFI \\
\hline i__19-3 & CKVLVSSRE \\
\hline Ri_4-14 & SYNELQRC- \\
\hline$\_14-33$ & KVLLTTF \\
\hline Ri_9-1 & ;KVLLTTR \\
\hline Ri_14-1 & SKVLLTTR \\
\hline Ri_14-20 & SKVLLTTR \\
\hline Ri_14-2 & KVLLTTR \\
\hline Ri_14-30 & KVLLTTR \\
\hline$-14-23$ & KVIITTF \\
\hline
\end{tabular}

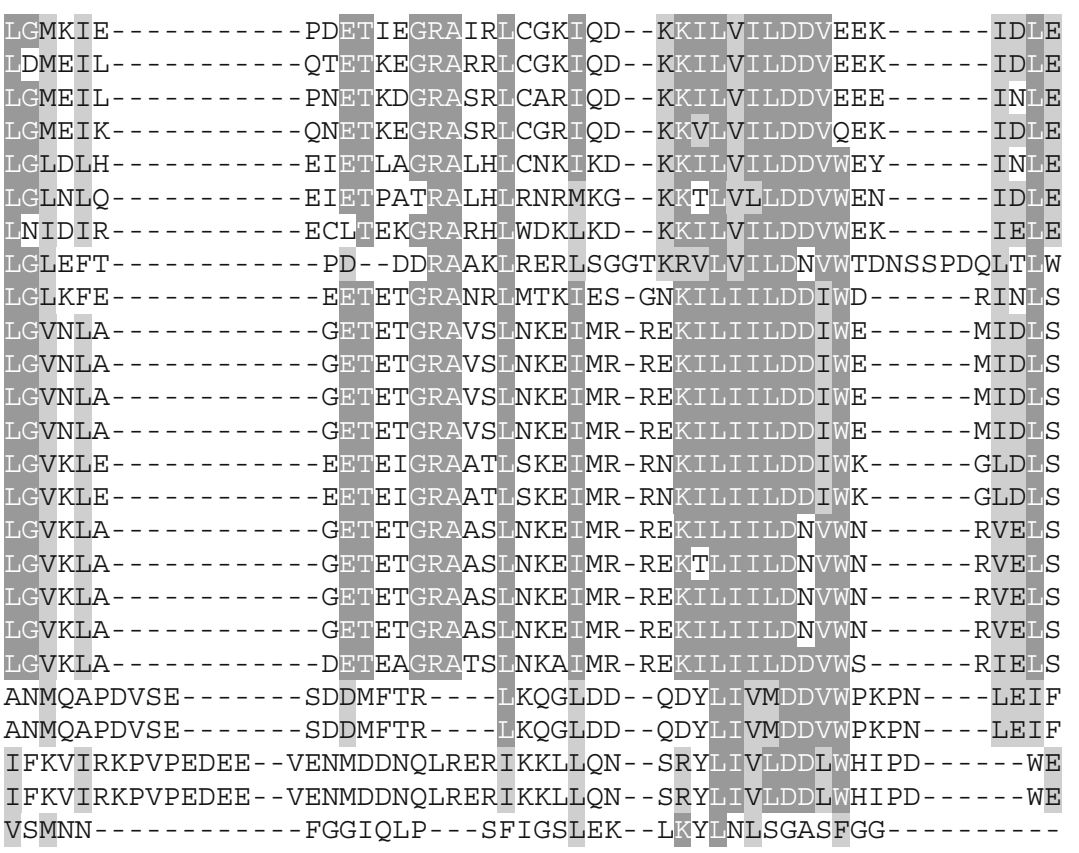

RNBS-B

RNBS-C

\section{Discussion}

Improvement of disease resistance is one of the main priorities in plant breeding. Markers developed through molecular techniques can be used for marker-assisted selection and eventually facilitate the map-based cloning of genes involved in the response to pests or other stresses. PCR approaches utilizing degenerate primers based on conserved NBS motifs from known disease-resistance genes have led to the cloning and identification of RGAs from many plant species (Kanazin et al. 1996; Leister et al. 1996; Yu et al. 1996; Aarts et al. 1998; Leister et al. 1998; TimmermanVaughan et al. 2000; Donald et al. 2002; Gaspero and Cipriani 2002; Tan et al. 2003; Zhang et al. 2003; Baldi et al. 
Fig. 3 (continued)

10_Ri_14-5 RIGVPGYKKLQTC-NSKVIITTRIKNTCT--SMHT-QEKIHLSVLSEKDSWISLFANTTGM 72_Ri_9-11 RIGVPGYKKLQTC-NSKVIITTRIKNTCT--SMHT-QEKIHLSVLSEKDSWSLFANTTGM 6_Ri_14-31 RIGVPGYKKLQTC-NSKVILTTRIKNTCT--AMHT-QEKIHLSVLSEKDSWSLFANTTGM 59.Rİ_4-7 RIGVPGYKKLQTC-NSKVILTTRMKNTCT--SMHT-QVKILLGVLSEKDSWSLFADTTGM 51_Ri_4-56 WTDICNILPTKVGKSSCIVITTRYKDIARGMVDQD-SQILQPSTLNEMIDSWSLFCRFAFR 53-Ri_4-58 WTDICNILPTKVGKSSCIVITTRYKDIARGMVEQD-SQILQPSTLNEVDSWSLFSRFAFR 24_Ri_4-13 TINHAMPNNNHGS - - RVMLTTRHVYVASASCLGNPDMLYHLEPLSPEDSWTLLCRRTFQ $27 \mathrm{Ri}^{4}-16$ TINHAMPNNNHGS - - RVMLTTRHAYVASASCLGNPDMLYRLEPLSPEDSWTLLCRKTFQ 8_Ri_14-35 --VIPPDLGNLSR - - - LLYLDLSNNAIES - - - - - - - - -DLRWLPSVSSLRFLNLGGAN

\begin{tabular}{|c|c|}
\hline & \\
\hline & \\
\hline & NG- - - - TP \\
\hline Ri_is-36 & NKRV - -GAY \\
\hline I_Ri__9-32 & NKMV - -SAY \\
\hline -Ri_9-30 & NKSV--SA \\
\hline 5_Ri_4-15 & NAHALGTEF \\
\hline -Ri_19-2 & RGEE--EN \\
\hline -Ri_4-19 & ------- \\
\hline -Ri_19-2 & SAPI - - - TE \\
\hline -Ri_19-7 & RCTQWFMVGY \\
\hline 5_Ri_6- & RCTQWFMVG \\
\hline $\mathrm{Ri}_{-} 6-2$ & VINQ- - - - N \\
\hline 9_Ri_6-5 & VINQ- - - - N \\
\hline 2_Ri_6-1 & VINQ----N \\
\hline 7_Ri_6-33 & VIHQ- - - - KS \\
\hline 3_Ri_6-35 & VINQ - - - NGGIRDVAIK \\
\hline 5_Ri_6-32 & IVKK-----TI \\
\hline -Ri_6-7 & IVEK-----PD \\
\hline 3_Ri_6-10 & VVKD--- - ERKREIAIHVS \\
\hline Ri_19-3 & --------- \\
\hline $\mathrm{Ri}^{-} 4-14$ & SFQK----SSDFYDVARKVI \\
\hline${ }_{\mathrm{R}} \mathrm{i} \_\overline{14}-33$ & SF-E----PTNFKDVARKVA \\
\hline$\overline{1}$ _R $\mathrm{i}$ _9-1 & SF-E--- - PTNFKDVARKVA \\
\hline 1_Ri_̄in-1 & SF-E--- - PTNFKDVARKVA \\
\hline 3_Ri_14-20 & SF-E----PTNFKDVARKVA \\
\hline Ri_14-2 & PF-E----SSTFEDVARRVA \\
\hline 5_Ri_14-30 & PF-E----SSTFEDVARRVA \\
\hline Ri_14-23 & SFDE-- - -SSELYNVARKVSI \\
\hline$\overline{0} \_\mathrm{R} \overline{\mathrm{i}} \_14-5$ & SFDE----SSELYNVARKVSNE \\
\hline 2_Ri_9-11 & SFDE----SSESYNVARKVSNE \\
\hline 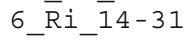 & SFDE----SS \\
\hline $5 \overline{9} \_\mathrm{R} \bar{i} \_4-7$ & SFDE----SS \\
\hline 1_Ri_4-56 & STDGK-SPDELFEKEG \\
\hline 3_Ri_4 & STDGK-CPDE \\
\hline$i_{-} 4-13$ & G-- - -NSCLP \\
\hline${ }^{-} \mathrm{Ri}_{-}^{-} 4-16$ & $\mathrm{G}----\mathrm{NS}$ \\
\hline Ri_e-14-35 & FTKAAPYWLPTVNMLPSLVE \\
\hline
\end{tabular}

2004; Xu et al. 2005, 2007). In this study, we have isolated 75 genomic fragments that revealed $50-87 \%$ similarity to NBS-LRR genes from other species, thus providing the first sampling of RGA sequences from red raspberry.

The percent nucleotide identity between the Rubus sequences identified ranged from 9\% (18_Ri_23-6, 74_Ri_9-32) to $100 \%$ (42_Ri_4-34, 38_Ri_4-28). The majority of sequences were widely divergent from each other. Only 20 pairs of sequences out of 5,550 pairwise comparisons showed more than $90 \%$ sequence identity between them. Probably there are many other RGA sequences in red raspberry, as only 75 amplified fragments based on seven primer combinations were analyzed. In fact, the NBS-LRR class of resistance genes has been shown to be very large in plants. For example, the genome of the model plant species $A$. thaliana is estimated to contain approximately 200 genes that encode related NBS motifs (Meyers et al. 1999). Red raspberry is diploid $(2 n=2 x=14)$ and has a small genome $(0.58 \mathrm{pg} / 2 \mathrm{C}, 280 \mathrm{Mbp} / 1 \mathrm{C})$, which compares favorably to $A$. thaliana with a genome size of $0.30 \mathrm{pg} / 2 \mathrm{C}, 145 \mathrm{Mbp} / 1 \mathrm{C}$ (Arumuganathan and Earle 1991), and so would be expected to proportionately have approximately 386 genes encoding NBS motifs.

It is likely that the RGA sequences with identity of more than $90 \%$ (20 pairs) have arisen from a recent duplication of a common ancestor gene. Unequal crossing-over is 
Fig. 4 Majority-rule consensus of 1,000 bootstrap replicates of a neighbor-joining cluster of Rosaceae RGA fragments (amino acid). Bootstrap confidence for branches more than $60 \%$ is reported. To conserve space, terminal clusters composed of sequences from a single genus are assigned a letter. Membership in these clusters is indicated in Supplemental Table S1. Individual sequences that do not group with others from the same genus are labeled with a number, taxonomic abbreviation, and as much of the original published ID as possible. Taxonomic abbreviations are: $F c$, Fragaria chiloensis; Fv, F. vesca; Fa, $F$. ananassa; $M b$, Malus baccata; Mp, M. prunifolia; $M d$, M. $\times$ domestica; Pa, Prunus armeniaca; $P p, P$. persica; Pc, Pyrus communis;

$R h$, Rosa hybrid cultivar; $R r, R$. roxburghii; Ri, Rubus idaeus. Terminal clusters of sequences derived from more than one genus with a bootstrap of more than $50 \%$ are assigned a Roman numeral. Mapped Rubus sequences are indicated with dashed lines and boxes. Sequences localized in a genome near resistance genes or QTLs are labeled: $A S$ apple scab, $B S$ bacterial spot, $N$ nematode, $P M$ powdery mildew, PRR Phytophthora root rot, $S$ sharka. a TIR Motif sequences. The original published classifications for these sequences are indicated in Supplemental Table S1. b non-TIR Motif sequences. The original published classifications for these sequences are indicated in Supplemental Table S1. These include non-TIR designations such as CC-NBS-LRR

Malus G, and LZ

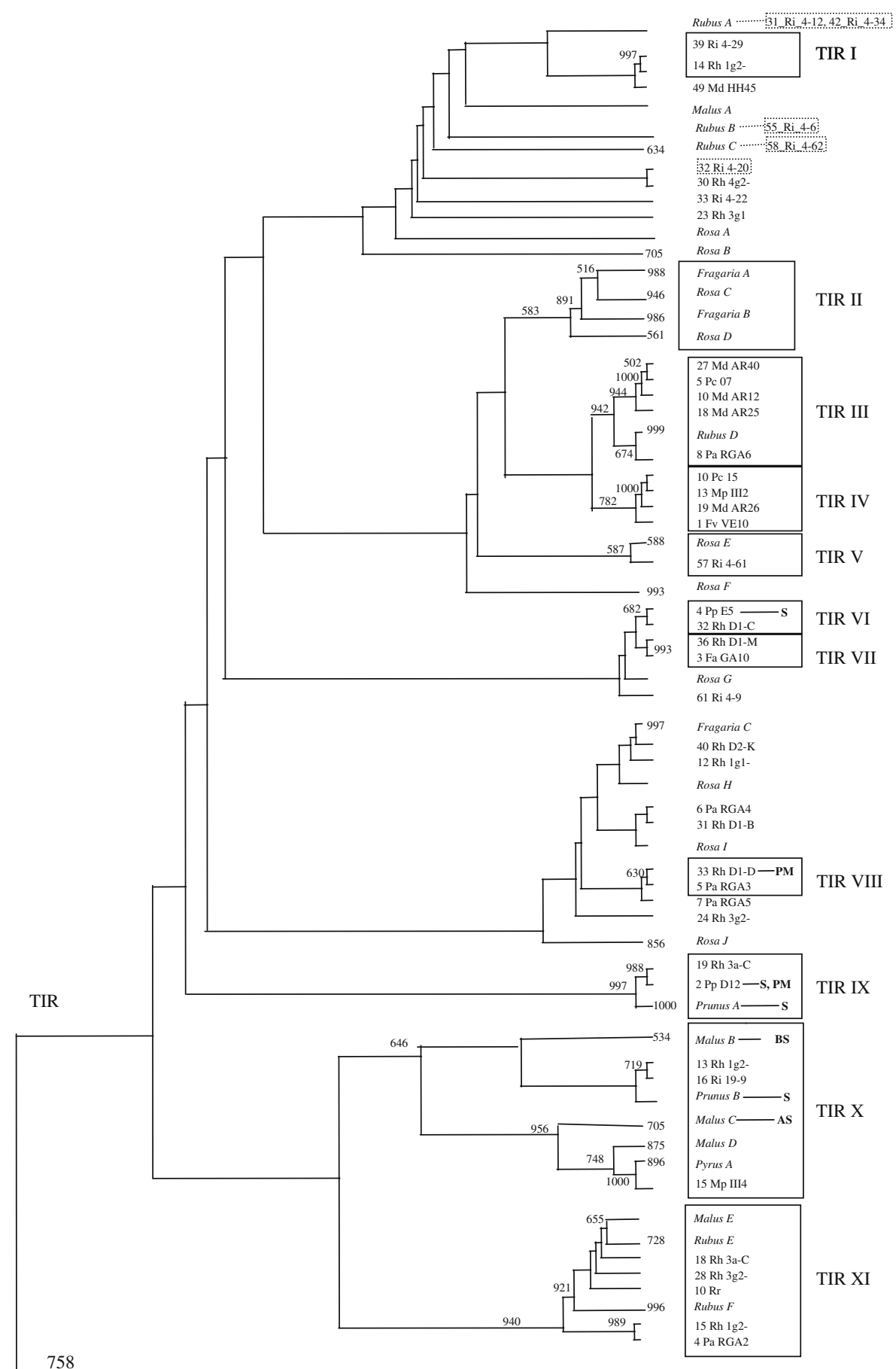

believed to be one mechanism through which this type of diversity is created in RGA clusters in plant genomes (Meyers et al. 1998). Alternatively, point mutations and/or small insertion/deletions in the regions between the conserved motifs may account for the genetic divergence between fragments of very high homology. Two main hypotheses have been proposed to explain the evolution of $R$ genes: the first suggesting that it is a result of slow evolving process (Michelmore and Meyers 1998; Stahl et al. 1999), while the second suggests a rapid evolution (Leister et al. 1998; McDowell et al. 1998). A greater degree of divergence was observed among the TIR-type 


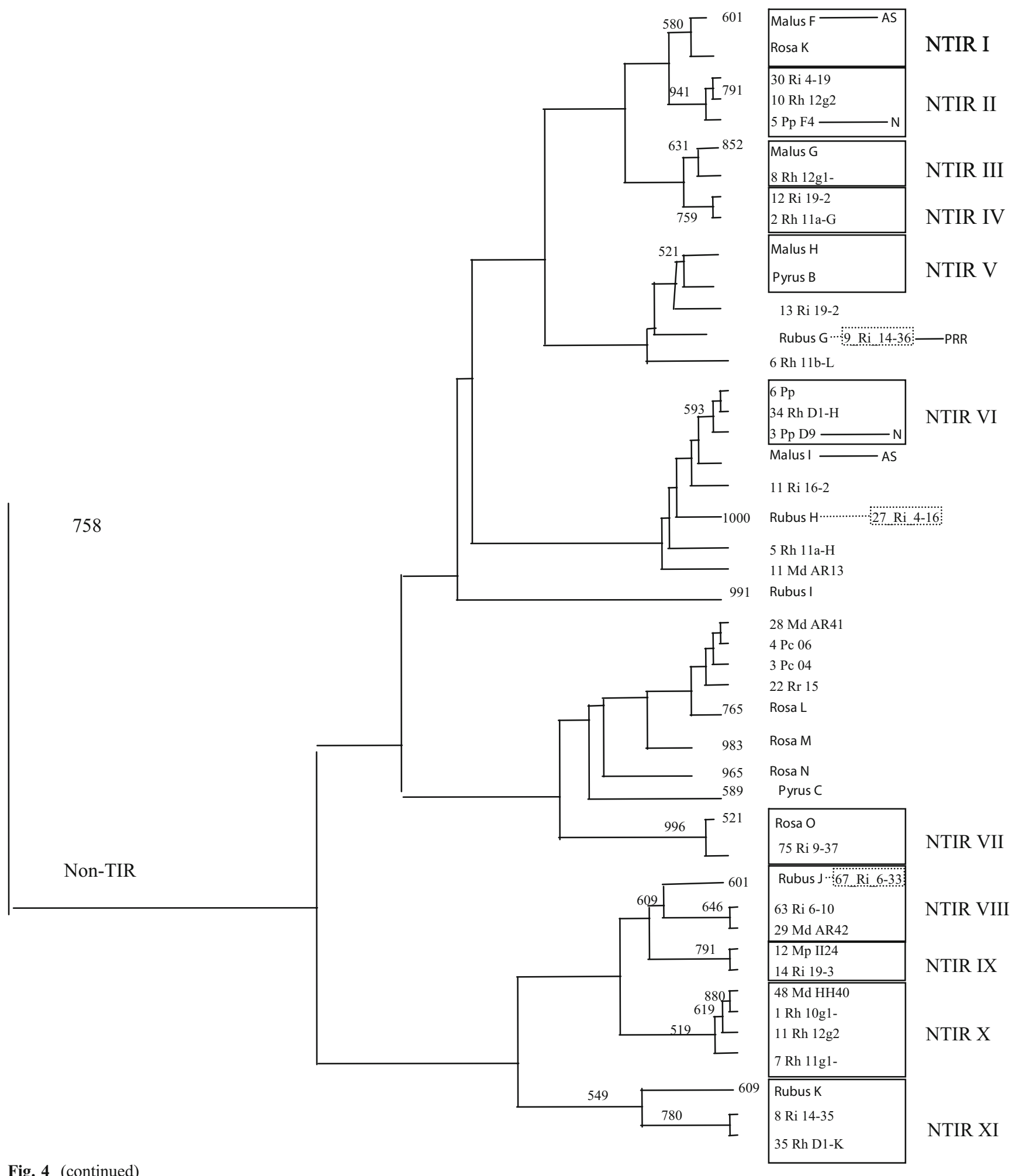

Fig. 4 (continued)

RGAs compared to the non-TIR-type RGAs suggesting that the former have been evolving more rapidly than the latter type. However, the full set of NBS-LRR sequences in red raspberry must be characterized to properly answer the question of which mechanism is responsible for the evolution of RGAs in this plant. Interestingly, evidence of functional resistance identified in other related plants clustered in TIR groups IX and X (four cases each, Fig. 4a). TIR X, 
in particular, has the most genera represented (5), and the most sequences (41). The evidence of both spread and number of sequences as well as conservation of function implies that the TIR X group may represent the ancestral Rosaceous TIR $\mathrm{R}$ gene from which additional RGA sequences evolved. Among the small TIR IX group, three of the four sequences are implicated in functional resistance. These two groups provide an intriguing target for further studies on $\mathrm{R}$ gene evolution and a likely source of functional polymorphism.

This study identifies 22 clusters with a bootstrap greater than $50 \%$ and more than one genus represented (Fig. $4 \mathrm{a}$ and b). A number of these clusters contain NBS-LRR sequences mapped near resistance QTL and loci from other species (Fig. 4a and b, Supplemental Table S1). Among the TIR type sequences, there were four such clusters. TIR IV, TIR VIII, TIR IX, and TIR X contain sequences linked to sharka (plum pox; Lalli et al. 2005), powdery mildew (Lalli et al. 2005), apple scab (Baldi et al. 2004), and bacterial spot resistance (Lee and Lee 2003). Three of the non-TIR type clusters (NTIR I, NTIR II, NTIR VI) contained sequences linked to root-knot nematode (Lalli et al. 2005) and apple scab (Baldi et al. 2004) resistance. None of 22 clusters identified here contained a mapped Rubus sequence; however, one Rubus sequence, located near a QTL for PRR resistance (Fig. 1), grouped with the larger clade containing clusters NTIR I to NTIR V (Fig. 4b).

The sequence relationships of RGA fragments share patterns with several previous studies that had a more limited taxonomic scope among the Rosaceae. Twenty of our 22 clusters (11 TIR, 9 non-TIR) corresponded to NBS-LRR clusters published in other studies (Supplemental Table S4). Six of the TIR clusters and three of the non-TIR clusters were corroborated by more than one additional study.

There was only one discrepancy between the sequence designation indicated by our neighbor-joining tree and those already published. Specifically, Baldi et al. (2004) designated ARGH 22 as a TIR sequence, while our analysis showed the same sequence (20_Md) to belong to the NTIR group (Supplemental Table S1). Only one "cluster" (really a paraphyletic group) designated by Hattendorf and Debener (2007) does not correspond with the sequence relationships found in this study; the "Rose-Pyrus" non-TIR group has members scattered among many of our non-TIR groups: NTIR IV, NBIR VII, and several other places in between (2_Rh_11a-G，6_Rh_11b-L，5_Rh_11a-H，3_Pc_04, 4_Rh_11a-G).

The overall agreement of all 14 studies of Rosaceae NBS-LRR sequences (including this one) indicates that these groupings are relatively robust. Each study used a different subset of data, and a variety of methods were used for analysis. Hattendorf and Debener (2007) shares seven clusters with this study, even though the clustering method used was very different (parsimony). Figure 1 of $\mathrm{Xu}$ et al. (2007) shares 15 clusters with this study, although it contains only 83 Rosaceae sequences and does not include R. hybrid or Rubus sequences.

Given the overall similarity of sequence fragments from multiple genera (as supported by bootstraps of more than $90 \%$ ), it seems probable that a significant proliferation of the RGA family occurred before the Rosaceae evolved into the different species present today. Large clusters of sequences, all from the same species, imply gene duplication after speciation (Xu et al. 2007). This pattern is seen for Rubus, Malus, Fragaria, and Rosa, but not for Prunus or Pyrus. However, it is difficult to compare the proliferation of particular NBS-LRR sequence types between specific Rosaceae using public data, as different primers and cloning procedures were used in each study. In this work, certain primer combinations tended to isolate related sequences. For example, the Rubus J group contains many products from the N6 primer and the Rubus K group many N4 products (Supplemental Table S1). Large clusters of similar sequences in Prunus or Pyrus might exist, but not have been detected, due to the way sequences were isolated. It would require strict control in methodology to generate the data necessary to address patterns of sequence proliferation between individual species.

RGAs are widely distributed in plant genomes and often organized in clusters (Kanazin et al. 1996; Meyers et al. 1999). In this study, eight RGA sequences were mapped in a previously developed red raspberry genetic map (Pattison et al. 2007) covering six out of the seven linkage groups. Clustering RGAs was not observed, probably due to the small amount of sequences mapped. Previous studies indicate that some RGAs might be genetically located at or near known resistance loci (Kanazin et al. 1996; Yu et al. 1996; Collins et al. 1998; Donald et al. 2002; Radwan et al. 2004). For example, two RGAs were found in close linkage to the nematode resistance locus Grol in potato (Leister et al. 1996), three RGA markers were linked to the citrus tristeza virus and nematode resistance in Citrus (Deng et al. 2000), and four RGA-derived markers (three RFLP markers and one STS marker) were found to be associated with CRPM1, a major R locus contributing to powdery mildew resistance in chestnut rose (Xu et al. 2005). Lalli et al. (2005) identified a number of RGAs near resistance QTL and other loci (Supplemental Table S1). In this study, one RGA marker (9_Ri 14-36) was mapped within the QTL for resistance to PRR (Pattison et al. 2007) on LG1 and might prove useful for marker-assisted selection. RGA marker(s) could not be co-localized with the second QTL for resistance to PRR. This result is not surprising because (1) a small portion of theoretically possible NBS-containing 
sequences from red raspberry have been identified, (2) the methods used did not allow the mapping of all the RGAs analyzed, and (3) not all QTL for resistance are necessarily associated with RGA sequences.

To date, few studies have been conducted toward the cloning and characterization of disease-resistance-related genes in red raspberry. Locating and mapping additional NBS-LRR homologues as well as the analyses of the RGAs mapped so far will help to accelerate the identification of genomic regions containing functional resistance genes and facilitate the long process of map-based cloning. This will lead to a better understanding of disease resistance in red raspberry and other plants and hopefully to the development of improved cultivars for commercial production that require fewer pesticides.

Acknowledgments This research was supported by a grant from the US Department of Agriculture - National Research Initiative (USDANRI) NYG-632526. We are grateful to William Boone for skillful technical work.

\section{References}

Aarts MGM, te Lintel Hekkert B, Holub EB, Beynon JL, Stiekema WJ, Pereira A (1998) Identification of R-gene homologous DNA fragments genetically linked to resistance loci in Arabidopsis thaliana. Mol Plant Microbe Interact 11:252-258

Afunian MR, Goodwin PH, Hunter DM (2006) Search for molecular markers linked to fire blight resistance in pear (Pyrus communis). Acta Hort (ISHS) 704:557-566

Arumuganathan K, Earle ED (1991) Nuclear DNA content of some important plant species. Plant Mol Biol Rep 9:208-218

Baker B, Zambryski P, Staskawicz B, Dinesh-Kumar SP (1997) Signaling in plant-microbe interactions. Science 276:726-733

Bent AF (1996) Plant disease resistance genes: function meets structure. Plant Cell 8:1757-1771

Baldi P, Patocchi A, Zini E, Toller C, Velaso R, Komjanc M (2004) Cloning and linkage mapping of resistance gene homologues in apple. Theor Appl Genet 109:231-239

Barritt BH, Crandall PC, Bristow PR (1979) Breeding for root rot resistance in red raspberry. J Amer Soc Hort Sci 104:92-94

Calenge F, Van der Linden CG, Van de Weg E, Schouten HJ, Van Arkel G, Denance C, Durel C-E (2005) Resistance gene analogues identified through the NBS-profiling method map close to major genes and QTL for disease resistance in apple. Theor Appl Genet 110:660-668

Collins NC, Webb CA, Seah S, Ellis JG, Hulbert SH, Pryor A (1998) The isolation and mapping of disease resistance gene analogs in maize. Mol Plant-Microb Interact 11:968-978

Dangl JL, Jones JDG (2001) Plant pathogens and integrated defense responses to infection. Nature 411:826-833

Deng Z, Huang S, Ling P, Chen C, Yu C, Weber CA, Moore GA, Gmitter FG Jr (2000) Cloning and characterization of NBS-LRR class resistance-gene candidate sequences in Citrus. Theor Appl Genet 101:814-822

Donald TM, Pellerone F, Adam-Blondon AF, Bouquet A, Thomas MR, Dry IB (2002) Identification of resistance gene analogs linked to a powdery mildew resistance locus in grapevine. Theor Appl Genet 104:610-618

Erwin DC, Ribeiro OK (1996) Phytophthora disease worldwide. APS Press, St. Paul, MN, p 562

Felsenstein J (2006) PHYLIP (Phylogeny Inference Package; http://evolution.genetics.washington.edu/phylip.html)

Flor HH (1971) Current status for the gene-for-gene concept. Ann Rev Phytopathol 9:275-296

Gaspero G, Cipriani G (2002) Resistance gene analogs are candidate markers for disease-resistance genes in grape (Vitis spp.). Theor Appl Genet 106:163-172

Hammond-Kosack KE, Jones JDG (1997) Plant disease resistance genes. Ann Rev Plant Physiol Plant Mol Biol 48:575-607

Hattendorf A (2005) Molekulargenetische Charakterisierung von Resistenzgenanaloga im Rosengenom als Basis fuer die Resistenzzuechtung. Dept Hort, Hannover, Germany, p 117 University of Hannover

Hattendorf A, Debener T (2007) Molecular characterization of NBS-LRR-RGAs in the rose genome. Physiol Plant 129(4): 775-786

Jones JDG (1996) Plant disease resistance genes: structure, function and evolution. Curr Opin Biotechnol 7:155-160

Kanazin V, Marek LF, Shoemaker RC (1996) Resistance gene analogs are conserved and clustered in soybean. Proc Natl Acad Sci USA 93:11746-11750

Karplus K, Barrett C, Hughey R (1998) Hidden Markov models for detecting remote protein homologies. Bioinformatics 14(10): $846-856$

Konieczny A, Ausubel FM (1993) A procedure for mapping Arabidopsis mutations using codominant ecotype-specific markers. Plant J 4:403-410

Lalli DA, Decroocq V, Blenda AV, Schurdi-Levraud V, Garay L, Le Gall O, Damsteegt V, Reighard GL, Abbott AG (2005) Identification and mapping of resistance gene analogs (RGAs) in Prunus: a resistance map for Prunus. Theor Appl Genet 111: $1504-1513$

Lee SY, Lee DH (2003) Putative TIR-NBS type R protein 4 [Malus baccata]: expression of the MbR4, a TIR-NBS type of apple $\mathrm{R}$ gene, confers resistance to bacterial spot disease in Arabidopsis. GenBank accessions http://www.ncbi.nlm.nih.gov

Lee SY, Lee DH (2006) TIR-NBS-LRR type R protein 7 [Malus baccata]: overexpression of the Apple MbR7 Encoding a TIR-NBS-LRR Type of R gene Induce Enhanced Resistance of transgenic Arabidopsis Infection with Bacterial Pathogen. GenBank accessions http://www.ncbi.nlm.nih.gov

Lee S-Y, Seo J-S, Rodriquez-Lanetty M, Lee D-H (2003) Comparative analysis of superfamilies of NBS-encoding disease resistance gene analogs in cultivated and wild apple species. Mol Gen Genomics 269:101-108

Leister D, Ballova A, Salamini F, Gebhardt C (1996) A PCR-based approach for isolating pathogen resistance genes from potato with a potential wide application in plants. Nat Genet 14:421-429

Leister D, Kurth J, Laurie DA, Yano M, Sasaki T, Devos K, Graner A, Schulze-Lefert P (1998) Rapid reorganization of resistance gene homologues in cereal genome. Proc Natl Acad Sci USA 95: 370-375

Liang FS, Kong FN, Zhou C-J, Cao P-X, Ye C-J, Wang B (2005) Cloning and characterization of a non-TIR-NBS-LRR type disease resistance gene analogue from peach. DNA Sequence 16:103-110

Martínez Zamora MG, Castagnaro AP, Díaz Ricci JC (2004) Isolation and diversity analysis of resistance gene analogues (RGAs) from cultivated and wild strawberries. Molec Genet Genomics 272:480-487 
McDowell JM, Dhandaydham M, Long TA, Aatrs MG, Goff S, Holub EB, Dangl JL (1998) Intragenic recombination and diversifying selection contribute to the evolution of downy mildew resistance at the RPP8 locus of Arabidopsis. Plant Cell 10: 1861-1874

Meyers BC, Chin DB, Shen KA, Sivaramakrishnan S, Lavelle DO, Zhang Z, Michelmore RW (1998) The major resistance gene cluster in lettuce is highly duplicated and spans several megabases. Plant Cell 10:1817-1832

Meyers BC, Dickerman AW, Michelmore RW, Sivaramakrishnan S, Sobral BW, Young ND (1999) Plant disease resistance genes encode members of an ancient and diverse protein family within the nucleotide-binding superfamily. Plant J 20:317-332

Michelmore RW, Meyers BC (1998) Clusters of resistance genes in plants evolve by divergent selection and a birth-and-death process. Genome Res 8:1113-1130

Paran I, Michelmore RW (1993) Development of reliable PCR-based markers linked to downy mildew resistance genes in lettuce. Theor Appl Genet 85:985-993

Pan Q, Wendel J, Fluhr R (2000) Divergent evolution of plant NBSLRR resistance gene homologues in dicot and cereal genomes. J Mol Evol 50:203-213

Pattison JA, Samuelian SK, Weber CA (2007) Inheritance of Phytophthora root rot resistance in red raspberry determined by generation means and molecular linkage analysis. Theor Appl Genet 115:225-236

Radwan O, Bouzidi MF, Nicolas P, Mouzeyar S (2004) Development of PCR markers of the PI5/PI8 locus for resistance to Plasmopara halstedii in sunflower, Helianthus annuus L. from complete CC-NBS-LRR sequences. Theor Appl Genet 109:176-185

Rehm BHA (2001) Bioinformatic tools for DNA/protein sequence analysis, functional assignment of genes and protein classification. Appl Microbiol Biotechnol Online article at http://link. springer.de/link/service/journals/00253/index.htm

Saraste M, Sibbald PR, Wittinghofer A (1990) The P-loop-a common motif in ATP- and GTP-binding proteins. Tr Biochem Sci 15: 430-434

Shen KA, Meyers BC, Islam-Faridi MN, Chin DB, Stelly DM, Michelmore RW (1998) Resistance-gene candidates identified by PCR with degenerate oligonucleotide primers map to clusters of resistance genes in lettuce. Mol Plant Microbe Interact 11: $1815-823$
Smith RF, Wiese BA, Wojzynski MK, Davison DB, Worley KC (1996) BCM Search Launcher-An integrated interface to molecular biology data base search and analysis services available on the World Wide Web. Genome Res 6:454-462

Soriano JM, Vilanova S, Romero C, Llácer G, Badenes ML (2005) Characterization and mapping of NBS-LRR resistance gene analogs in apricot (Prunus armeniaca L.). Theor Appl Genet 110:980-989

Stahl EA, Dwyer G, Mauricio R, Kreitman M, Bergelson J (1999) Dynamics of disease resistance polymorphism at the Rpm1 locus of Arabidopsis. Nature 400:667-671

Tan H, Callahan FE, Zhang X-D, Karaca M, Saha S, Jenkins JN, Creech RG, Ma D-P (2003) identification of resistance gene analogs in cotton (Gossypium hirsutum L.). Euphytica 134:1-7

Timmerman-Vaughan GM, Frew TJ, Weeden NF (2000) Characterization and linkage mapping of R-gene analogous DNA sequences in pea (Pisum sativum L.). Theor Appl Genet 101: $241-247$

Van Oijen JW, Voorrips RE (2001) JoinMap 3.0 ${ }^{\mathbb{R}}$, software for the calculation of genetic linkage maps. Plant Research International, Wageningen, The Netherlands

Varshochi A (2006) Putative CC-NBS-LRR resistance protein [Malus $\times$ domestica]: Sequencing of a Malus domestica BAC associated with resistance to Dysaphis devecta. GenBank accessions. http://www.ncbi.nlm.nih.gov

Wilcox WF, Pritts MP, Kelly MJ (1999) Integrated control of Phytophthora root rot of red raspberry. Plant Dis 83:1149-1154

Xu Q, Wen X, Deng X (2005) Isolation of TIR and nonTIR NBS-LRR resistance gene analogues and identification of molecular markers linked to a powdery mildew resistance locus in chestnut rose (Rosa roxburghii Tratt). Theor Appl Genet 111:819-830

Xu Q, Wen X, Deng X (2007) Phylogenetic and evolutionary analysis of NBS-encoding genes in Rosaceae fruit crops. Mol Phylogenet Evol 44:315-324

Yu YG, Buss GR, Maroof MAS (1996) Isolation of a superfamily of candidate disease resistance genes in soybean based on a conserved nucleotide-binding site. Proc Natl Acad Sci USA 93: $11751-11756$

Zhang LP, Lin GY, Niño-Liu D, Foolad MR (2003) Mapping QTLs conferring early blight (Alternaria solani) resistance in a Lycopersicon esculentum $\times$ L. hirsutum cross by selective genotyping. Mol Breeding 12:3-19 